\section{Kastamonu Eğitim Dergisi Kastamonu Education Journal}

Temmuz 2019 Cilt:27 Sayı:4

kefdergi.kastamonu.edu.tr
Başvuru Tarihi/Received: 6.07 .2018

Kabul Tarihi/Accepted: 24.09.2018

DOI: $10.24106 /$ kefdergi.3214

\title{
Üniversite Öğrencilerinin Psikolojik Yardım Alma ve Romantik ílişki Durumunun Gestalt Temas Biçimleri Açısından İncelenmesi ${ }^{1}$
}

\section{Analysis of the State of Receiving Psychological Help and Romantic Relationships of University Students in Terms of Gestalt Contact Styles}

\author{
Sema YAZICl ${ }^{2}$, Mustafa ŞAHIN ${ }^{3}$
}

\section{Öz}

Bu araştırmada üniversite öğrencilerinin psikolojik yardım alma ve romantik ilişki durumunun yanı sıra cinsiyetlerinin ve ebeveyn tutumlarının Gestalt temas biçimleri açısından incelenmesi amaçlanmaktadır. Çalışma grubu çeşitli üniversitelerde eğitim almakta olan 794 üniversite öğrencisinden oluşmaktadır. Veri toplama aracı olarak "Gestalt Temas Biçimleri Yeniden Düzenlenmiş Formu" ve araştırmacı tarafindan hazırlanan "kişisel bilgi formu" kullanılmıştr. Veriler SPSS 18.0 paket programı ile analiz edilmiştir. Verilerin analizinde "t-testi" ve "tek yönlü varyans analizi" teknikleri kullanmıştır. Araştırma sonuçları üniversite öğrencilerinin Gestalt temas biçimleri ile cinsiyet, algılanan anne-baba tutumu, romantik ilişki durumu ve psikolojik yardım alma durumu arasında anlamlı ilişkiler olduğunu göstermektedir. Bu doğrultuda elde edilen bulgular ilgili literatür çerçevesinde tartışılmış ve bazı önerilerde bulunulmuştur.

Anahtar Kelimeler: anne-baba tutumu, cinsiyet, gestalt temas biçimi, psikolojik yardım alma, romantik ilişki

\begin{abstract}
In this research, it is aimed to investigate university students' the state of receiving psychological help and romantic relationship status as well as gender and parental attitudes in terms of Gestalt contact styles. The study group consists of 794 university students studying at various universities. "Personal information form" and "Gestalt Contact Styles Revised Form" prepared by the researcher were used as data collection tools. The data were analyzed with the SPSS 18.0 package program. In the analysis of the data, "t-test" and "one way analysis of variance" techniques were used. The results of the research show that there is a significant relationship between Gestalt contact styles of university students and gender, perceived parental attitude, romantic relationship status and the state of receiving psychological help. The findings obtained in this direction are discussed in the related literature and some suggestions are presented.
\end{abstract}

Keywords: gender, gestalt contact style, parental attitude, romantic relationship, the state of receiving psychological help

1. Bu çalışma, birinci yazarın ikinci yazar danışmanlığında hazırlamış olduğu yüksek lisans tezinden üretilmiştir.

2. Recep Tayyip Erdoğan Üniversitesi, Eğitim Fakültesi, Eğitim Bilimleri Bölümü, Rize, Türkiye, https://orcid.org/0000-0002-5221-6829.

3. Trabzon Üniversitesi, Eğitim Fakültesi, Eğitim Bilimleri Bölümü, Trabzon, Türkiye, https://orcid.org/0000-0002-5721-6211.

Atıf / Citation: Yazıcı, S., \& Şahin, M. (2019). Üniversite öğrencilerinin psikolojik yardım alma ve romantik ilişki durumunun gestalt temas biçimleri açısından incelenmesi. Kastamonu Education Journal, 27(4), 1649-1658. doi:10.24106/kefdergi. 


\section{Extended Abstract}

Purpose and Significance: A person who comes to the world as a social entity reveals himself through relationships and maintains his/her life. The concept of contact, one of the most important concepts that the Gestalt Therapy approach, which is set in motion with an idea in this direction, focuses on the way in which individuals communicate with the environment and the functionality of these styles. It is thought that the quality of contacts that are realized to be effective and functional in every area of life is extremely important for the individual. Understanding the styles of contact that are shaped by the various stimuli, life events, physical and emotional experiences and diverse learnings they meet from the moment individuals are born are crucial to making it easier to find inferences about individuals' behavioral patterns. In order to understand the styles of contact that are shaped and manifested by many factors, it is necessary to examine them in terms of various variables. When the literature is considered, it is seen that the number of researches on this concept, which has an important place in terms of social behaviors and lives of the individuals, is very few in the national and international field. Taking all these facts into consideration, it was aimed to investigate the university students' the state of receiving psychological help and romantic relationship status as well as gender and parental attitudes in terms of Gestalt contact styles.

Method: The study group of the study is university students who are studying in Artvin, Rize, Trabzon, Ankara, Istanbul, Kocaeli, Karabük in 2016-2017 academic year. In the scope of the study, 910 students were reached and 100 scale forms which were found to be incomplete and incorrectly filled were taken out and 810 scale forms were made. Skewness and Kurtosiss values were examined and 16 scale forms containing extreme values were obtained.The study group consisted 469 women and 325 male. The Gestalt Contact Styles Scale-YDF and the personal information form developed by the researcher were used to collect the data. It took approximately 15-20 minutes to complete the questionnaires administered to volunteer students during a one month period during the 2016-2017 academic year. SPSS 18 package program was used for the analysis of the obtained data. Relationships between gestalt contact styles and various variables were tested using "t-test" and "One-way ANOVA".

Results: When gender contact patterns were examined in terms of gender variation, only a significant difference was found in the emotional desensitization sub-dimension. Men's emotional desensitization contact form scores were higher than women. When gestalt contacts were perceived in terms of perceived parental attitude change, it was seen that individuals with democratic parental attitude in deflection and retroreflection subscales had lower average scores than the other groups. In the case of contact, the opposite is true. ie individuals with democratic parental attitudes in this sub-dimension have a higher average than the other groups. In the form of intercontact contact, the scores of the indifferent parents were lower than those of the democratic and protective parents. Finally, emotional desensitization was found to be low in relation to the average of individuals with a democratic parental attitude in contact with individuals with a high but unrelated parental attitude according to the averages of the individuals with protective parental attitudes. In terms of romantic relationship variables, the average of individuals with no romantic relationship in the retroreflection sub-dimension was higher whereas the average of individuals with romantic relationship was found higher in contact dimension. Finally, when gestalt contact styles were examined in terms of the state of receiving psychological help variable, it was determined that only the average of individuals who received psychological help in the deflection and retroreflection sub dimensions were significantly higher than those who did not.

Discussion and Conclusions: When the related literature is examined, it is seen that the researches related to the subject are very limited. It can be said, however, that the findings obtained from the present study overlap with those obtained from this study. Previous styles of contact have been reached in the context of gender change in the way in which emotional desensitization contacts men more than women. This result obtained in this research can be considered within the framework of the meaning attributed to the characteristics of male and female personality in the structure of Turkish society and the way of cultivation in this direction. It has been observed that individuals with democratic parental attitudes as well as those who use functional forms of contact more frequently. This finding, supported by previous research, also shows that the modes of upbringing are highly effective in communicating with the environment. As well as being exposed to family attitudes that do not allow the individual to develop social, personal and psychological, may cause them to reflect these deficiencies into their relationships when communicating with the environment. Can be explained by the fact that non-romantic individuals use more of their retroreflection contact form and try to come from above because they can not fulfill their needs that they have to satisfy through close relationships. Except that romantic associations have a higher average in the contact sub-dimension, overlapping with the definition of the concept of contact. because the contact refers to the ability to establish and maintain interrelationships. The fact that clients are using more of the styles of contact and diversion are associated with the emergence of these styles of contact as negative perceptions of the world. So it is thought that those who have such attitudes and thoughts are likely to be more likely to have psychological problems and eventually to receive psychological help.

Communication is a very important element at every stage of human life. People can only survive by communicating. Thus increasing the amount of research to be done on this area is important for better understanding of the forms of communication and human behavior that are crucial for the individual. As well as the fact that contact modalities are handled in terms of different variables and in different ways, the literature will provide significant contributions. 


\section{Giriş}

Gestalt tabanlı düşünceden ortaya çıkan uygulamaları bir çatı altında toplayan Gestalt Terapisi insanla ilgili kapsamlı ve derinlemesine çabaları daha yenilikçi bir bakış açısıyla bütünleştiren bir kuramdır. Tarihsel sürece bakıldığında bir psikoterapi yaklaşımı olarak adlandırılan Gestalt Terapi, felsefi temelleri olması, çeşitli radikal fikirleri birleştirmesi gibi özellikleri açısından psikoterapi alanından çok daha geniş etkilere sahiptir (Levin, Bar, \& Levine, 2012: 1). Fritz Perls tarafindan ortaya konulan Gestalt kuramının gelişmesinde Laura Perls, Ralp Hefferline ve Paul Goodman gibi araştırmacllar da önemli rol oynamıştır (Özkara, 2015).

Gestalt terapinin epistemolojik temelleri alan teorisini, fenomenolojik yaklaşımı ve bütüncüllüğü esas alır (Evans, 2007). "Şimdi ve Burada" yı vurgulayan Gestalt terapi yaklaşımı bu özelliğinden dolayı varoluşçu, bireyin algıları üzerinde odaklandığı için ise fenomenolojik olarak değerlendirilebilir. Bunun yanı sıra bireyin yaşadıklarını ve düşündüklerini deneyimlemesine dayanan Gestalt terapisi bütüncül bir kuram olarak da ele alınabilir. Bu temeller üzerinde oluşturulan Gestalt Terapi süreci üç evreye ayırılabilir. Bu evreler; farkında olma, özümseme ve bütünleşmedir (Acar, 2016).

Gestalt Terapisinin temel kavramlarından biri olan "temas" kavramı, var olma güdüsü taşıyan insanın varlığını anlamlandırabilmesi, sosyal bir varlık olarak yaşamını sürdürebilmesi ve ihtiyaçlarını karşılayabilmesi için iletişim kanallarına yönelerek çevreyle iletişim halinde olmasını ifade eder (Kuyumcu, 2011; Tagay, \& Acar, 2012). Gestalt terapinin en önemli kavramlarından olan temas kavramı, bireyin çevresi ile iletişim kurarken kullandığı yöntemler olarak da tanımlanabilir (Gürdil, 2009).

Temasın varoluşsal anlamda değerli bir unsur olduğunu dile getiren Perls, üç temas alanından bahsetmiştir. Bunlar; bireyin kendisi ile yaşadığı, bulunduğu dünya ile yaşadığı ve fantezileri yoluyla yaşadığı temas alanlarıdır. Bireylerin büyümesi ve gelişmesi, bu temas alanlarına ilişkin farkındalıkların artmasıyla mümkündür (Sakarya, 2003). Temasta nesnel gerçekliği pasif olarak almak yerine aktif bir araştırma süreciyle seçmek, yorumlamak ve düzenlemekten bahsedilir (Wheeler, \& Axelsson, 2015: 20). Temas kurarken beş duyu organımızı kullanmamız gerekir. Temas kurmak için bakmak, dinlemek, görmek, duymak, konuşmak, dokunmak, hareket etmek, koklamak, tatmak gibi yöntemleri kullanabiliriz. Bu yollarla farkındalık kazanmaya temas işlevleri denir (Acar, 2015, 52). İnsanların yaşant ve tecrübeleri sonucunda oluşan temas biçimleri diğer insanlarla nasıl iletişim kurduğumuzu belirleyen bir unsurdur. Temas biçimleri kişinin hayatını kolaylaştrabileceği gibi aşırı kullanımı kişiye zarar vererek temas bozukluklarına sebebiyet de verebilir (Vardal, 2015). Temas biçimleri, kişinin yaşamına olumlu katkılar sağlayabileceği gibi, durumu uygun olmayan sürekli kullanımlarda bazı sorunlara yol açabilirler. Bu şekilde bir davranım temas döngüsünü kesintiye uğratarak problemlere yol açabilir (Bozkurt, 2006).

Gestalt terapi kuramında yedi temas biçiminden söz edilmektedir. Bu temas biçimleri içe alma, iç içe geçme, geri döndürme, duyarsızlaşma, yansıtma, saptırma ve kendini seyretme olarak adlandırılmaktadır. Geri döndürme temas biçimi kişinin ihtiyaçlarını karşılamak için harcaması gereken enerjiyi çevreye yöneltmesinden ziyade kendine yöneltmesi durumunu ifade eder ve bu temas biçiminde benlik, ihtiyacı karşılanan kimse ve ihtiyacı karşılayan kimse olarak iki kısma ayrıı ır (Perls, Hefferline, \& Goodman, 1951, 1966). Saptırma temas biçimi, doğrudan temas kurmaktan kaçınarak dolaylı yolları kullanmak olarak ifade edilir (Gürsoy, 2009). Duyarsızlaşma temas biçimi, bireylerin çevresel uyaranlara ilişkin fiziksel ve duygusal uyaranları hissedebilecek mekanizmaya sahip olmasına rağmen kendilerini rahatsı eden durumlardan kaçınmak için bilinçli olarak duyumlarını dikkate almamaları durumunu ifade eder (Özkara, 2015). Kendini seyretme temas biçimi, bireylerin çevreyle temas kurmaktan çok çevreyle temas kurma aşamasında nasıl göründüklerine odaklanması durumunu ifade eder (Gürsoy, 2009). Yansıtma temas biçimi, benliğin bileşenlerini oluşturan duyguları, fikirleri ve değerleri başkaları ile ilişkilendirerek onlara aitmiş gibi davranmayı ifade eder (Myers, 1996). İ̧̧ içe geçme temas biçimi, kişilerin sınırlarının yok olarak bir başkasıyla bütünleşmesi durumudur ve bu temas biçiminde bireyin benliğine ilişkin algılarının öteki kişilerden ayrışamaması söz konusudur (Mann, 2010). İçe alma temas biçimi ise kişilerin çevreden gelen mesajları, öğrenmesi ve özümsemesi yoluyla benliğine dâhil etmesi şeklinde tanımlanır (Tagay, \& Acar, 2012).

Sosyal bir varlık olarak dünyaya gelen insan kendini ilişkileri yoluyla ortaya koyar ve yaşamını bu şekilde sürdürür. Yaşamın her alanında etkin ve işlevsel olabilmek için gerçekleştirilen temasların niteliğinin, bireyler açısından son derece önemli olduğu düşünülmektedir. Fakat Gestalt terapi yaklaşımına göre temas, sadece bireyin kendisi ya da çevresi ile ilişkili bir süreç olarak görülmemekte, aksine bu iki unsurun karşılıklı etkileşimi sonucunda ortaya çıkan bir olgu olarak değerlendirilmektedir (Daş, 2015) Birçok faktörden etkilenerek şekillenen ve birey tarafindan ortaya konulan temas biçimlerinin anlaşılabilmesi için çeşitli değişkenler açısından incelenmesi ise son derece önemli görülmektedir. Literatür ele alındığında, bireylerin sosyal davranışları ve yaşamları açısından önemli bir yere sahip olan bu kavrama ilişkin 
araştırmaların sayısının ulusal ve uluslararası alanda oldukça az olduğu dikkat çekmektedir. Temas kavramının daha iyi anlaşıması, doğasının ortaya konulması ve kişi-çevre etkileşimi ile ilgili boyutunun daha iyi değerlendirilebilmesi için kavramın çeşitli değişkenlerle ilişkisinin ortaya konulmasının önemli olduğu düşünülmektedir. Bu doğrultuda, bu araştırmada üniversite öğrencilerinin Gestalt temas biçimlerinin cinsiyet, algılanan anne-baba tutumu, romantik ilişki durumu ve psikolojik yardım alma durumu açısından incelenmesi amaçlanmıştır.

\section{Yöntem}

\section{Araştirma Modeli}

Bu araştırma tarama modeline uygun olarak ortaya konulmuştur. Tarama modelinde var olan bir durumun nesnel gerçekliği içerisinde olduğu gibi ortaya koymak esastr. Bu araştrma modelinde bağımlı değişken kendi koşulları içinde gözlenerek, olduğu gibi ortaya konulmaya çalışılmıştır (Karasar, 2013).

\section{Çalışma Grubu}

Araştırmanın çalışma grubunu 2016-2017 yılı eğitim-öğretim yılında Artvin, Rize, Trabzon, Ankara, İstanbul, Kocaeli, Karabük illerinde eğitim görmekte olan üniversite öğrencileri oluşturmaktadır. Çalışma kapsamında 910 öğrenciye ulaşılmış olup eksik ve yanlış doldurulduğu tespit edilen 100 adet ölçek formu çıkarılarak 810 adet ölçek formu analizlere dahil edilmiştir. Daha sonra Çarpıklık-Basıklık değerleri doğrultusunda uç değerleri içeren 16 ölçek formu çıkarılarak 794 kişi ile veri analizleri gerçekleştirilmiştir. Araştırmanın katılımcılarına ilişsin betimsel istatistik dağııımları Tablo 1'de özetlenmiştir.

Tablo 1. Katılımcılara ilişkin tanımlayıcı istatistikler

\begin{tabular}{lccc}
\hline Değişken & Faktör & $\mathrm{n}$ & $\%$ \\
\hline \multirow{2}{*}{ Cinsiyet } & Kız & 469 & 59,1 \\
& Erkek & 325 & 40,9 \\
& Demokratik & 327 & 41,2 \\
Algıınan Anne-Baba Tutumu & Koruyucu & 384 & 48,4 \\
& Otoriter & 53 & 6,7 \\
& Illgisiz & 30 & 3,8 \\
Romantik Ilişki & Var & 129 & 29,1 \\
& Yok & 563 & 70,9 \\
Psikolojik Yardım & Aldım & 129 & 16,2 \\
& Almadım & 665 & 83,8 \\
\hline Toplam & & 794 & 100 \\
\hline
\end{tabular}

\section{Veri Toplama Araçları}

\section{Demografik Bilgi Formu}

Kişisel bilgi formu katılımcıların Gestalt Temas Biçimleri ile ilişkili olabileceği düşünülen bilgileri elde etmek amacıyla araştırmacı tarafindan hazırlanmıştr. 4 sorudan oluşan Kişisel Bilgi Forumu’nda öğrencilerin cinsiyetleri, algıladıkları anne baba tutumları, romantik ilişkileri olup olmadığı ve psikolojik yardım alıp almadıkları ile ilgili bilgiler elde edilmeye çalışılmıştır.

\section{Gestalt Temas Biçimleri Ölçeği Yeniden Düzenlenmiş Formu}

Woldt ve Kepner tarafindan 1986 yılında geliştirilen GTBÖ, alt alt boyutu içeren 100 maddeden oluşmaktadır. Aktaş ve Daş (2002) tarafindan Türkçe'ye uyarlanan GTBÖ için yapılan geçerlik ve güvenirlik çalışmaları sonucunda ölçek beş alt boyuttan oluşan 61 maddeye indirgenmiştir. Ölçeğin faktör yapısını ortaya koymaya yönelik olarak yapılan analizler sonucunda ölçeğin, geri döndürme, saptırma, temas, iç içe geçme ve duygusal duyarsızlaşma şeklinde adlandırılan 5 faktörden oluştuğu görülmüştür. Beşli likert tipi şeklinde hazırlanan ölçeğin gruplara uygulanması uygundur ve uygulama esnasında süre sınırlaması yoktur. Cevap seçenekleri "bana oldukça uygun", "bana uygun", "kararsızım", "bana 
uygun değil" ve "bana hiç uygun değil" şeklindedir. Ölçeğin güvenirliği belirlenirken madde alt boyut toplam korelasyonları hesaplanmıştr. Bu hesaplamanın sonucunda madde faktör toplam korelasyonları geri döndürme için .31 ile .56 arasında; saptırma için .20 ile .53 arasında; temas için .17 ile .45 arasında; iç içe geçme içi .19 ile .45 arasında; duygusal duyarsızlaşma için ise .19 ile .35 arasında bulunmuştur. Ölçeğin bu hali ile geçerli ve güvenilir olduğu düşünülmektedir (Gökdemir, 2002). Ölçeğin bu çalışma için hesaplanan Cronbach Alpha ( $\alpha$ ) değerlerinin alt boyutlarda .63 ile .78 arasında değiştiği bulunmuştur.

\section{Veri Toplama Süreci ve Veri Analizi}

Veriler 2016-2017 akademik yılı güz döneminde gerekli izinlerin alınmasıyla çeşitli üniversitelerde öğrenim gören öğrencilere uygulanmıştr. Uygulama öncesinde öğrencilere katılımın gönüllülük esasına dayalı olduğu hakkında bilgi verilmiş ve araştırmanın amacı kısaca anlatıımıştr. Katılım için gönüllü olan öğrencilere veri seti dağıtılmış olup, ortalama 15-20 dakikalık bir süre içinde tüm sorulara yanıt vermişlerdir. Ölçekler yaklaşık bir aylık bir süre içerisinde uygulanarak tamamlanmıştr. Verilerin analizi araştırmacı tarafindan SPSS 18 paket programı ile gerçekleştirilmiştir. Gestalt temas biçimleri ile çeşitli değişkenler arasındaki ilişkiler " $t$-testi" ve "tek yönlü varyans analizi" kullanılarak test edilmiştir.

\section{Bulgular}

\section{Üniversite Öğrencilerinin Gestalt Temas Biçimlerinin Cinsiyet Değişkeni Açısından İncelenmesi}

Gestalt Temas Biçimlerinin cinsiyet değişkenine göre anlamlı bir şekilde farklılaşıp farklılaşmadı̆̆ını tespit etmek için bağımsız $t$ testi kullanılmıştır ve yapılan analize ilişkin bulgular Tablo $2^{\prime}$ de verilmiştir.

Tablo 2. Gestalt temas biçimlerinin cinsiyet değişkenine göre incelenmesi

\begin{tabular}{|c|c|c|c|c|c|}
\hline Değişken & Cinsiyet & Ortalama & Standart Sapma & $t$ & $p$ \\
\hline \multirow{2}{*}{ Geri Döndürme } & Erkek & 54.05 & 10.33 & \multirow{2}{*}{-.155} & \multirow{2}{*}{.87} \\
\hline & Kız & 53.94 & 9.98 & & \\
\hline \multirow{2}{*}{ Saptirma } & Erkek & 35.10 & 9.00 & \multirow{2}{*}{-.709} & \multirow{2}{*}{.47} \\
\hline & $\mathrm{K} ı \mathrm{z}$ & 34.66 & 8.05 & & \\
\hline \multirow{2}{*}{ Temas } & Erkek & 38.82 & 5.83 & \multirow{2}{*}{.325} & \multirow{2}{*}{.74} \\
\hline & $\mathrm{K} ı \mathrm{Z}$ & 38.95 & 5.57 & & \\
\hline \multirow{2}{*}{ İç İçe Geçme } & Erkek & 43.88 & 5.59 & \multirow{2}{*}{1.482} & \multirow{2}{*}{.13} \\
\hline & $\mathrm{K} \mathrm{Iz}$ & 44.49 & 5.76 & & \\
\hline \multirow{2}{*}{ Duygusal Duyarsızlaşma } & Erkek & 18.13 & 3.71 & \multirow{2}{*}{-12.160} & \multirow{2}{*}{$.00 *$} \\
\hline & $\mathrm{K} \mathrm{IZ}$ & 14.86 & 3.72 & & \\
\hline
\end{tabular}

$* p<.05$

Analizler sonucunda katlımcıların Gestalt temas biçimlerinden geri döndürme, saptırma, temas ve iç içe geçme alt boyutlarında cinsiyet değişkeni açısından anlamlı bir farklıık olmadığı; fakat duygusal duyarsızlaşma alt boyutunda anlamlı bir farklııık olduğu görülmüştür. Erkek öğrencilerin duygusal duyarsızlaşma temas biçimi puan ortalamaları, kız öğrencilerin puan ortalamalarından anlamlı düzeyde yüksektir ( $t=-12.160, p<.05)$.

\section{Üniversite Öğrencilerinin Gestalt Temas Biçimlerinin Algılanan Anne-Baba Tutumu Değişkeni Açısından İncelen- mesi}

Üniversite öğrencilerinin Gestalt temas biçimlerinin algılanan anne-baba tutumuna göre anlamlı bir şekilde farklılaşıp farklılaşmadığını test etmek amacıyla yapılan tek yönlü varyans analizi (ANOVA) sonuçları Tablo 3’ de verilmiştir. 
Tablo 3. Anne baba tutumuna göre temas biçimlerine ilişkin farklılıklar

\begin{tabular}{|c|c|c|c|c|c|c|}
\hline Değişken & Faktör & Kareler Toplamı & Serbestlik Derecesi & Kareler Ortalaması & $\mathrm{F}$ & $p$ \\
\hline \multirow{3}{*}{ Geri Döndürme } & Gruplar içi & 2608.926 & 3 & 869.642 & \multirow{3}{*}{8.732} & \multirow{3}{*}{$.000^{*}$} \\
\hline & Gruplar arası & 78680.827 & 790 & G 50 & & \\
\hline & Toplam & 81289.753 & 793 & 99.596 & & \\
\hline \multirow{3}{*}{ Saptirma } & Gruplar içi & 1676.718 & 3 & 558.906 & \multirow{3}{*}{8.035} & \multirow{3}{*}{$.000^{*}$} \\
\hline & Gruplar arası & 54949.968 & 790 & \multirow{2}{*}{69.557} & & \\
\hline & Toplam & 56626.686 & 793 & & & \\
\hline \multirow{3}{*}{ Temas } & Gruplar içi & 259.866 & 3 & 86.622 & \multirow{3}{*}{2.704} & \multirow{3}{*}{$.044^{*}$} \\
\hline & Gruplar arası & 25305.247 & 790 & \multirow{2}{*}{32.032} & & \\
\hline & Toplam & 25565.113 & 793 & & & \\
\hline \multirow{3}{*}{ İç İçe Geçme } & Gruplar içi & 260.760 & 3 & 86.920 & \multirow{3}{*}{2.693} & \multirow{3}{*}{$.045^{*}$} \\
\hline & Gruplar arası & 25496.726 & 790 & \multirow{2}{*}{32.274} & & \\
\hline & Toplam & 25757.486 & 793 & & & \\
\hline \multirow{3}{*}{ Duygusal Duyarsızlaşma } & Gruplar içi & 214.832 & 3 & 71.611 & \multirow{3}{*}{4.429} & \multirow{3}{*}{$.004^{*}$} \\
\hline & Gruplar arası & 12773.727 & 790 & \multirow{2}{*}{16.169} & & \\
\hline & Toplam & 12988.559 & 793 & & & \\
\hline
\end{tabular}

$* p<.05$

Yapılan ANOVA testi sonuçlarına göre Gestalt temas biçimlerinden Geri Döndürme, Saptırma, Temas, İç İçe Geçme ve Duygusal Duyarsızlaşma alt boyutlarının algılanan anne-baba tutumuna göre anlamlı bir farklılık gösterdiği tespit edilmiştir $(F(3,790)=8.732, p<.05)$. Farkın kaynağını araştırma için yapılan LSD Post-Hoc testi sonuçlarına göre demokratik anne-baba tutumuna sahip olan bireylerin geri döndürme puanlarının (ort=52.04); koruyucu (ort=54.86), otoriter (ort=57.85) ilgisiz (ort=57.07) anne-baba tutumuna sahip olanlardan anlamlı düzeyde düşük olduğu belirlenmiştir. Saptirma alt boyutunda demokratik anne-baba tutumuna sahip olan bireylerin puanlarının (ort=33.27); koruyucu (ort=35.57), otoriter (ort=37.75) ve ilgisiz (ort=37.53) anne-baba tutumuna sahip olanlardan anlamlı düzeyde düşük olduğu belirlenmiştir. Temas alt boyutunda demokratik anne-baba tutumuna sahip olan bireylerin puanlarının (ort=39.50); koruyucu (ort=38.64), otoriter (ort=37.60) ve ilgisiz (ort=37.93) anne-baba tutumuna sahip olanlardan anlamlı düzeyde yüksek olduğu belirlenmiştir. İç içe geçme alt boyutunda ilgisiz anne-baba tutumuna sahip olan bireylerin puanlarının (ort=41.37); demokratik (ort=44.29) ve koruyucu (ort=44.42) anne-baba tutumuna sahip olanlardan anlamlı düzeyde düşük olduğu belirlenmiştir. Duygusal Duyarsızlaşma alt boyutunda ise demokratik anne-baba tutumuna sahip olan bireylerin puanlarının (ort=16.59); koruyucu (ort=15.73) anne-baba tutumuna sahip olan bireylerden anlamlı düzeyde yüksek, ilgisiz (ort=17.83) anne-baba tutumuna sahip olan bireylerden anlamlı derecede düşük olduğu belirlenmiştir.

\section{Üniversite Öğrencilerinin Gestalt Temas Biçimlerinin Romantik ilişki Durumu Değişkeni Açısından İncelenmesi}

Gestalt Temas Biçimlerinin romantik ilişki durumuna göre anlamlı düzeyde farklılaşıp farklılaşmadığı bağımsız $t$ testi ile incelenmiştir. Analizlere ilişkin bulgular Tablo 4'te özetlenmiştir.

Tablo 4. Gestalt temas biçimlerinin romantik ilişki durumu değişkeni açısından incelenmesi

\begin{tabular}{|c|c|c|c|c|c|c|}
\hline Değişken & Romantik ilişski & $\mathrm{N}$ & Ortalama & Standart Sapma & $t$ & $p$ \\
\hline \multirow{2}{*}{ Geri Döndürme } & Var & 231 & 51.95 & 10.22 & \multirow{2}{*}{-3.655} & \multirow{2}{*}{$.00 *$} \\
\hline & Yok & 563 & 54.82 & 9.97 & & \\
\hline \multirow{2}{*}{ Saptirma } & Var & 231 & 34.00 & 8.77 & \multirow{2}{*}{-1.788} & \multirow{2}{*}{.07} \\
\hline & Yok & 563 & 35.18 & 8.29 & & \\
\hline \multirow[b]{2}{*}{ Temas } & Var & 231 & 40.51 & 5.48 & \multirow[b]{2}{*}{5.224} & \multirow[b]{2}{*}{$.00 *$} \\
\hline & Yok & 563 & 38.23 & 5.62 & & \\
\hline \multirow{2}{*}{ İç İçe Geçme } & Var & 231 & 44.36 & 5.49 & \multirow{2}{*}{.388} & \multirow{2}{*}{.69} \\
\hline & Yok & 563 & 44.19 & 5.78 & & \\
\hline \multirow{2}{*}{ Duygusal Duyarsızlaşma } & Var & 231 & 15.97 & 4.11 & \multirow{2}{*}{-1.003} & \multirow{2}{*}{.31} \\
\hline & Yok & 563 & 16.29 & 4.02 & & \\
\hline
\end{tabular}

${ }^{*} p<.05$

Tablo 4 incelendiğinde görülmektedir ki romantik ilişkisi olan öğrencilerin Geri Döndürme temas biçimi puan ortalamaları romantik ilişkisi olmayan öğrencilere göre anlamlı düzeyde düşüktür ( $t=-3.655, p<.05)$. Öte yandan romantik ilişkisi olan öğrencilerin "Temas" temas biçimi puan ortalamaları, romantik ilişkisi olmayan öğrencilerin puan ortalama- 
larından anlamlı düzeyde yüksektir ( $t=5.224, p<.05)$. Bunun yanı sıra romantik ilişki durumu değişkeni açısından Gestalt temas biçimlerinden saptırma, iç içe geçme ve duygusal duyarsızlaşma temas biçimlerinde anlamlı farklılıklar ortaya çıkmamıştr.

\section{Üniversite Öğrencilerinin Gestalt Temas Biçimlerinin Psikolojik Yardım Alma Değişkeni Açısından İncelenmesi}

Üniversite öğrencilerinin Gestalt temas biçimlerinin ile psikolojik yardım alma değişkenine göre anlamlı bir farklılık gösterip göstermediği $t$ testi ile incelenmiş ve sonuçlar Tablo 5' de gösterilmiştir.

\section{Tablo 5. Gestalt temas biçimlerinin psikolojik yardım alma değişkeni açısından incelenmesi}

\begin{tabular}{|c|c|c|c|c|c|c|}
\hline Değişken & Psikolojik Yardım Alma & $\mathrm{N}$ & Ortalama & $\begin{array}{c}\text { Standart } \\
\text { Sapma }\end{array}$ & $t$ & $p$ \\
\hline \multirow[b]{2}{*}{ Geri Döndürme } & Aldım & 129 & 57.65 & 11.17 & \multirow[b]{2}{*}{4.553} & \multirow[b]{2}{*}{$.00^{*}$} \\
\hline & Almadım & 665 & 53.27 & 9.75 & & \\
\hline \multirow[b]{2}{*}{ Saptirma } & Aldım & 129 & 36.49 & 8.85 & \multirow[b]{2}{*}{2.428} & \multirow[b]{2}{*}{$.01^{*}$} \\
\hline & Almadım & 665 & 34.52 & 8.33 & & \\
\hline \multirow[b]{2}{*}{ Temas } & Aldım & 129 & 39.01 & 5.64 & \multirow[b]{2}{*}{.248} & \multirow[b]{2}{*}{.80} \\
\hline & Almadım & 665 & 38.87 & 5.68 & & \\
\hline \multirow[b]{2}{*}{ İç İçe Geçme } & Aldım & 129 & 43.78 & 5.89 & \multirow[b]{2}{*}{-1.005} & \multirow[b]{2}{*}{.31} \\
\hline & Almadım & 665 & 44.33 & 5.66 & & \\
\hline \multirow[b]{2}{*}{ Duygusal Duyarsızlaşma } & Aldım & 129 & 15.94 & 4.36 & \multirow[b]{2}{*}{.800} & \multirow[b]{2}{*}{.42} \\
\hline & Almadım & 665 & 16.25 & 3.98 & & \\
\hline
\end{tabular}

${ }^{*} p<.05$

Katılımcılardan daha önce psikolojik yardım alan öğrencilerin Geri Döndürme temas biçimi puan ortalamalarının, daha önce psikolojik yardım almayan öğrencilerin puan ortalamalarından anlamlı düzeyde yüksek olduğu görülmüştür $(t=4.553, p<.05)$. Bunun yanı sıra daha önce psikolojik yardım alan öğrencilerin Saptırma temas biçimi puan ortalamala$\mathrm{rı}$, daha önce psikolojik yardım almayan öğrencilerin puan ortalamalarından anlamlı düzeyde yüksektir $(t=2.428, p<.05)$. Psikolojik yardım alma durumu açısından Gestalt temas biçimlerinden temas, iç içe geçme ve duygusal duyarsızlaşma temas biçimlerinde anlamlı farklılıklar olmadığı görülmüştür.

\section{Sonuçlar}

Üniversite öğrencileriyle yürütülen bu araştırmada Gestalt temas biçimleri cinsiyet, psikolojik yardım alma, algılanan anne-baba tutumu ve romantik ilişki durumu değişkenleri açısından incelenmiştir. Araştırma bulguları göstermektedir ki Gestalt Temas Biçimleri Ölçeği Yeniden Düzenlenmiş Formunda ölçülen temas biçimlerinde ilgili değişkenler açısından anlamlı farklilıklar vardır.

Heiden (2006) temas kavramını bireylerin iç ve dış uyarımını yönlendiren belirli davranış biçimleri olarak açıklamaktadır. Bireyin kendisi, bulunduğu dünya ve fantezileri ile yaşadığı üç temas alanı olduğunu ifade eden Perls; temas yoluyla bireyin nesnel gerçekliği aktif bir şekilde seçtiği ve yorumlayarak düzenlediğini ifade etmektedir (Wheeler, \& Axelsson, 2015, 20). Vardal (2015) temas biçimlerinin insanların yaşantı ve tecrübeleri sonucunda oluştuğunu ifade ederek; temas biçimlerinin çeşitli değişkenler tarafindan etkilenebileceğini ileri sürmektedir.

Cinsiyet değişkeni bireylere yönelik toplumsal algıları şekillendiren, bireye belirli davranış kalıplarını ifade eden toplumsal rolleri veren ve bireye ilişkin beklentileri ortaya çıkaran bir olgudur. Bireylerin çevreyle temasları sürecinde kullandıkları tarzları ortaya koymalarında önemli bir faktör olan cinsiyet kavramı, temas biçimleri açııından incelendiğinde kişinin duygularına yönelik hassasiyetini kaybetmesi olarak ifade edilebilecek olan duygusal duyarsızlaşma temas biçimini, erkeklerin kadınlara göre daha fazla kullandığı görülmektedir. Benzer şekilde Sakarya (2008) üniversite öğrencileriyle yapmış olduğu araştırmasında çalışma grubuna dâhil edilen tüm erkeklerin duygusal duyarsızlaşma temas biçiminde kadınlardan anlamlı düzeyde farkılış̧tklarını ifade etmiştir. Bunun yanı sıra Gürsoy'un (2009) kız ve erkek öğrencilerle, Kuyumcu'nun (2011) evli bireylerle yapmış olduğu çalışmalarda ve Vardal'ın (2015) çalışmasında da benzer bulgular elde edilmiştir. Bu araştırmanın bulguları da erkeklerin kadınlara göre duygusal duyarsızlaşma temas biçimini daha fazla kullandığını gösteren araştırma sonuçlarıyla benzerlik içerisindedir. İlgili literatür incelendiğinde ve Türk toplumunun aile yapısı göz önüne alındığında kadın ve erkek bireyler arasında duygu ile ilgili farkıııkların olduğu görülmektedir. Toplumsal beklentiler ve kadınların yetiştirilme tarzları, kadınların daha duygusal, ilişkilere önem veren özgeci bireyler olmaları yönündedir. Erkek bireylerde ise toplumsal beklentiler duygusal hassasiyetin yerini mantıksal çıkarımların alması yönündedir. Bu doğrultuda daha önce yapılan çalışmalarla da örtüşen bulgular, Türk toplum yapısı ve psikolojik şemalar dikkate alındığında erkeklerin duygusal duyarsızlaşma temas biçimini daha çok kullanmasını açıklar niteliktedir. 
Romantik ilişki kavramı ise bir başkasına karşı yoğun duyguları ifade eden kişisel bir ilişki olarak tanımlanmakta ve yakınlık, bağlanma, güven, saygı ve sevgi gibi duyguları barındırmaktadır. Yakınlık ihtiyacı içerisinde olan bireyler daima başkalarına intiyaç duymaktadır (Atak, \& Taştan, 2012). Bireylerin çevreyle nasıl iletişim kurduğuna ilişkin bir gösterge olarak ele alınabilecek olan romantik ilişki durumu değişkeni, Geştalt temas biçimleri açısından incelendiğinde geri döndürme temas biçimini romantik ilişki olmayan bireylerin daha fazla, iç içe geçme temas biçimini ise romantik ilişkisi olan bireylerin daha fazla kullandığı görülmüştür. İlgili literatürde doğrudan bu değişkenler ile yapılan bir çalışmaya rastlanmamaktadır fakat Büyükşahin (2001) yaptı̆̆ı çalışmasında ailesiyle yaşayan ve yaşamayan üniversite öğrencilerinden romantik ilişkisi olanların olmayanlara göre kaygılı bağlanma stilinde farklıık gösterdiğini bulmuştur ve romantik ilişkisi olmayan öğrencilerin duygusal yalnızlı̆ı daha fazla hissettiğini saptamıştı. Geri döndürme temas biçimi bireyin ihtiyaçlarını giderecek davranışlarla ilgili taleplerinin sonuçları hakkında endişe duyduğu zamanlarda söz konusu davranışı kendilerine yaparak, davranışlarının hedefi olarak kendilerini belirlemesi şeklinde ifade edilmiştir (Daş, 2015, 173). Bu bağlamda kaygılı bağlanma stiliyle olumsuz duygulara odaklanma eğilimi ve endişe saplantıları, olumsuz duygulanımlar ve kişisel ilişki anlamında benzerlik gösteren bu iki kavrama ilişkin elde edilen bulguların benzeştiği görülmektedir. Romantik ilişkinin çeşitli ihtiyaçları gidermeye yönelik kişilerarası teması gerektiren bir faktör olması geri döndürme temas biçimini sıklıkla kullanan bireylerin korku, kaygı gibi sebeplerden dolayı romantik ilişki yaşamasını engelleyen bir neden olabilir. Bunun yanı sıra geri döndürme temas biçimini kullanan bireylerin ilişkilerindeki intiyaçlarını bir öteki olmadan karşılama eğiliminde olmaları ilişkisel anlamda yalnızlık hissetmelerine sebep olabilecek bir faktördür. Bu iki sonuç birbiriyle paralellik göstermekte ve örtüşmektedir. Aynı zamanda temas alt boyutunda romantik ilişkisi olan bireylerin puanlarının anlamlı düzeyde yüksek olması da bireylerin duygusal ve sosyal intiyaçlarını romantik ilişkiler içerisinde gidermeye yönelmesi ile açıklanabilir. Bireyler bu ihtiyaçları gidermek için temas kurma eğiliminde oldukları takdirde yakın ilişkiler kurmak için daha güçlü motivasyon kaynaklarına sahip olurlar.

Ruh sağlığını sağlama ve sürdürmede önemli bir yere sahip olan psikolojik yardım hizmetleri, bireyin yaşamında baş edemediği durumlar ortaya çıktğında başvurduğu bir kaynaktır (Leong, 2008). Bireylerin ruhsal durumlarının çevre ile kurdukları iletişim üzerinde etkili olabileceği düşünülmektedir. Bu durumu ele almak için Gestalt temas biçimleri, psikolojik yardım alma durumu açısından incelendiğinde geri döndürme ve saptırma temas biçimlerinde psikolojik yardım alanların ortalamalarının, almayanlara göre daha yüksek olduğu tespit edilmiştir. Benzer sonuçlara ulaşan Bozkurt (2006) yapmış olduğu araştirmada psikolojik yardım almayan katıımcıların temas ve duygusal duyarsızlaşma temas biçimlerini psikolojik yardım alan katılımcılara göre anlamlı düzeyde daha fazla kullandıklarını belirtmiştir. Aynı çalışmada psikolojik yardım alan grubun almayan gruba oranla geri döndürme ve saptırma temas biçimlerini anlamlı olarak daha fazla kullandıklarını bulan Bozkurt (2006), iki grubun farklılaşmadığı tek temas biçiminin iç içe geçme olduğunu ifade etmiştir. Gökdemir-Aktaş ve Daş (2002) ise yaptıkları çalışmada psikolojik yardım alanların saptırma temas biçimini almayanlara göre anlamlı düzeyde daha fazla kullandığıı gösteren bulgulara ulaşırken, Balkaya (2006) da benzer şekilde psikolojik yardım alan kişilerin almayanlara oranla geri döndürme temas biçimini daha fazla kullandığını saptamıştır. Geri döndürme temas biçiminin bireyin çevreyle iletişim kurmaktan kaçınarak, enerjisini kendisine yönlendirmesi olduğu daha öncede ifade edilmiştir. Sapttrma temas biçimi de bireylerin doğrudan temas kurması yerine dolaylı yolları tercih etmesi şeklinde tanımlanabilir. Söz konusu temas biçimlerinin ihtiyaçların ortaya çıkması ve temasın kurulması aşamasında kullanılması, bireylerin çevreyle etkileşim kurmasını ve ihtiyaçlarını gidermesini engelleyerek psikolojik sorunların oluşmasına neden olan bir zemini hazırladığı düşünülebilir. Dolayısıyla bulgular, bu temas biçimlerini kullanan bireylerin çeşitli psikolojik problemler yaşadığı ve bunun neticesinde psikolojik yardım arayışına girdiği şeklinde yorumlanabilir. illgili literatür de bu bulguları destekler niteliktedir. Burley ve Freier (2004) birey ve dünya arasındaki ilişkinin niteliğinin nasıl olacağını belirleyen ilk öğrenmelerin kaynağı olan ebeveynlerin, temas kavramı için çok önemli bir yere sahip olduğunu ifade etmiştir. Bu ilişki bireylerin dünya görüşünü ve dünyayla iletişime geçme yöntemlerini etkileyen önemli bir faktördür. Bu araştırmanın da ortaya çıkardığı sonuçlar göstermiştir ki anne-baba tutumları bireylerin temas biçimleri üzerinde önemli etkilere sahiptir. Bu doğrultuda bireylerin çevre ile etkileşiminde etkili olabilecek bir unsur olan geri döndürme ve sapttrma temas biçiminde demokratik anne baba tutumuna sahip bireylerin ortalamalarl; ilgisiz, koruyucu ve otoriter anne baba tutumuna sahip olan bireylere göre daha düşük çıkmıştır. Anne baba tutumları arasında en sağılıkı olarak nitelendirilebilecek demokratik anne baba tutumuna sahip ebeveynlerin çocuklara sağladığı yetişme ortamının hoşgörülü, destekleyici ve güven verici olması beklenir. Böyle bir ortamda yetişen bireylerin sosyal ve duygusal anlamda yeterli, iletişim kurma becerileri yüksek, kendine ve insanlara güvenebilen, bağımsız ve sorumluluk sahibi bireyler olmaları beklenir. Burada bahsedilen sosyal ve kişisel yeterliliklerin aksine geri döndürme ve saptrrma temas biçiminde bireyler sosyal iletişim kurma, davranışlarının sorumluluklarını üstlenebilme, kendine güvenme gibi noktalarda sorun yaşamaktadırlar. Bu doğrultuda demokratik anne baba tutumuna sahip ebeveynlerin yetiştirdiği bireylerin bu temas biçimlerini daha az kullanması sonucu gözükmektedir.

Araştırma sonuçları göstermiştir ki temas temas biçiminde demokratik anne-baba tutumuna sahip bireylerin ortalamaları diğer gruplara göre daha yüksektir. Gestalt terapi kuramının en önemli kavramlarından biri olan temas biçimleri bireylerin dünyayı anlaması ve onu şekillendirmesini sağlayan bir araç olarak ele alınır. Temas alt boyutu da bireylerin temas kurma düzeylerini ifade eden bir alt boyuttur. Bu doğrultuda demokratik anne-baba tutumuna sahip ebeveynler tarafindan yetiştirilen bireyler; güven verici, iletişim düzeyinin yüksek olduğu ve kendilerini ifade edebildikleri bir ortamda yetiştiklerinden (Baumrind, 1996) çevreyle temas kurma ve sağ Iıklı ilişkiler geliştirme becerilerinin daha yüksek olması beklenir. Bunun aksine ilgisiz

| Kastamonu Eğitim Dergisi, 27(4), 2019| 
anne baba tutumuna sahip ebeveynler çocuklarına karşı kayıtsız davranır ve onları önemsemezler. Bu tür ortamlarda yetişen çocukların saldırgan olması, iletişim sorunları yaşaması ya da özgüveni düşük bireyler olması söz konusudur. Dolayısıyla ilgisiz anne-baba tutumuna sahip olan bir kişi çevreye karşı tereddütlü ve güvensiz bir yaklaşım sergileyeceğinden (Kaya, 1997) temas kurmaktan kaçınacak ve ihtiyaçlarını gidermek için asgari düzeyde temas kurmayı tercih edecektir. Koruyucu anne baba tutumunda ise ebeveynler çocuklarını aşırı derecede korur ve kontrol ederler. Her şeyi çocukları yerine kendileri yaparak onların öğrenme yaşantılarını engellerler. Bu şekilde yetişen bireyler karar verme becerileri ve öz-yeterliliği düşük kimseler olabilir. Koruyucu anne-baba tutumuna sahip bir bireyin çoğu zaman çevreyle temas kurması engellenmiş olacağından öz-yeterliliği düşük bir birey olacaktır (Yavuzer, 1990) ve ihtiyaçlarını karşılamayı ya da iletişim kurmayı başka kanallar üzerinden halletmeye çalışacaktr. Otoriter anne-baba tutumuna sahip ebeveynler tarafindan yetiştirilen bireyler ise ürkek, çekingen, özgüveni düşük ve tek başına iş yapabilme becerileri düşük kişilik özelliklerine sahip olurlar (Maccoby ve Martin, 1983). Dolayısıyla bu bireylerde özerk bir şekilde temas kurma becerileri zayıf ve temas kurma düzeyleri düşük olabilir.

Araşttrma sonucunda iç içe geçme temas biçimini, ilgisiz anne baba tutumuna sahip bireylerin demokratik ve koruyucu anne baba tutumuna sahip bireylere göre daha az kullandıkları görülmüştür. İç içe geçme temas biçiminde bireyin sevdiği biriyle arasındaki sınırların yok olması durumu söz konusudur; fakat ilgisiz anne baba tutumuna sahip bireylerde özdeşleşilen ve yakınlık hissedilen bir ebeveyn figürü olmadığı için bu temas biçiminin diğerlerine göre düşük kullanımı mümkün gözükmektedir.

Araştırma sonuçlarına göre duygusal duyarsızlaşma temas biçiminin koruyucu anne baba tutumuna sahip bireylerde, demokratiklere göre daha düşük çıkmıştr. Bu durumun koruyucu anne baba tutumuna sahip olan bireylerin, yaşam olaylarıyla yüzleşme firsat bulamaması sonucunda dayanıklılıklarının düşük olması ve durumlar karşısında ortaya koydukları duygusal tepkilerinin daha yoğun olmasıyla ilişkili olabileceği düşünülmektedir. Buna karşın demokratik anne baba tutumuna sahip olan bireylerin daha öncede baş etmek durumunda kaldıkları yaşam olaylarının olmasının, tepki eşiklerinin yüksek olmasına neden olacağı ve bunun da bazı durumlara karşı duygusal olarak duyarsız kalabilmelerini sağlayabileceği düşünülmektedir. Benzer şekilde ilgisiz anne baba tutumuna sahip bireylerde duygusal duyarsızlaşmanın daha çok kullanılmasının nedeni bu şekilde yetişen bireylerin birçok yaşam olayını yalnız başına tecrübe etmek durumunda kalmaları sonucu dayanıkılık ve tepki düzeylerinin daha yüksek olması olabilir. Bunun yanı sıra, bu iletişim örüntüsünün bir başa çıkma yöntemi olarak kullanıyor olmaları olabilir.

Araştırmadan elde edilen bulgulara dayalı olarak temas biçimlerinin anne-baba tutumu ile yakından ilişkili bir kavram olduğu sonucu ortaya çıkmıştır. Şüphesiz çocukların doğduğu andan itibaren içinde bulunduğu ortam ve bu ortamın onlara sağladığı öğrenme yaşantıları çevreleriyle kurdukları iletişimi, kişiliklerini, neler hissedeceklerini etkileyen önemli bir faktördür. Bu doğrultuda temas ve duygusal farkındalık konularıyla ilgili velilere yönelik yapılacak çalışmalar daha sağlıklı bireyler yetiştirmemizi sağlayacak önemli bir unsurdur. Bunun yanı sıra cinsiyet değişkeni açısından ortaya çıkan farkıııılar göstermektedir ki iletişim biçimleri birtakım kültürel kodlardan etkilenmektedir. Bu durumun ele alınması bireylerin davranışlarını açıklamakta faydalı sonuçlar doğurabilir.

\section{5. Öneriler}

Bu çalışma sonuçları göstermektedir ki temas biçimleri ile anne-baba tutumları arasında anlamlı bir ilişki vardır. Bireylerin içinde yetiştikleri çevrenin mimarları olan ve onların ilk öğrenmelerinin kaynağı olan anne babalarıyla olan ilişkilerinin onların çevreyle kurdukları temas üzerinde etkili bir faktör olması son derece önemli bir bulgudur. Bu bulgu doğrultusunda temas biçimleri ve anne-baba tutumlarıyla ilgili olarak ebeveynlere yönelik geliştirilecek olan psiko-eğitim programlarının geliştirilmesinin daha sağlıkı temas örüntüleri ortaya koyabilen bireyler yetiştirilmesi açısından faydalı olabileceği düşünülmektedir.

Romantik ilişki durumuna göre geri döndürme ve temas alt boyutlarında ortaya çıkan anlamlı farklılık, yakın kişiler arası ilişkiler bağlamında temas biçimlerinin önemini göstermektedir. Olumlu yakın ilişkiler kurup, geliştirmek, bireylerin varoluşuna katkı sağladığı gibi bir ihtiyaç olarak da ele alınabilir. Aynı zamanda bir gelişim görevi olan yakın ilişkiler açııından temas biçimlerinin önemli olduğu düşünülmektedir. Bu kapsamda ortaya çıkan uyum problemleri ve bunların sağaltımı noktasında temas biçimlerini göz önünde bulundurarak yapılacak olan müdahalelerin geliştirilmesi ve etkililiğinin sınanmasının alana önemli katkılar sağlayabileceği düşünülmektedir.

Psikolojik yardım alma durumuna göre temas biçimleri ele alındığında ise daha çok aşırı kullanımının olumsuz olarak nitelendirildiği temas biçimlerine sahip bireylerin psikolojik yardım aldığı görülmektedir. Bu durumun bireylerin temas biçimlerinin olumsuz ve uyumsuz bir örüntüye sahip olmasının çeşitli psikolojik problemlere yol açtğı̆ı gösterdiği düşünülmektedir. Bu anlamda sosyal ilişkiler ve psikolojik problemlerle temas biçimleri arasındaki ilişkinin farklı çalışmalarla ortaya konulmasının psikolojik problemlere neden olan değişkenlere ilişkin literatürü genişleterek yeni bakış açıları sağlamaya yardımcı fikirler ortaya konulmasına katkı sağlayabileceği düşünülmektedir.

Yapılan bu araştırma çalışma grubuyla sınırıdır. Gestalt temas biçimleri ise yaş, sosyo-ekonomik düzey, yaşam dönemi vb. psikolojik, sosyolojik ve kültürel değişkenler açısından incelenmesi gereken önemli bir psikoloji alanı konusudur. Bu nedenle 
bu tarz çalışmaların farklı örneklemler üzerinde ve farklı değişkenlerle ele alınması temas biçimlerini anlamayı ve uygulama alanında etkin olarak kullanmaya katkı sağlayacağı düşünülmektedir.

\section{Kaynakça}

Acar, N. V. (2015). Gestalt terapi: Ne kadar farkındayım? (6.Basım). Ankara: Nobel Yayıncılık.

Atak, H., \& Taştan, N. (2012). Romantik ilişkiler ve aşk. Psikiyatride Güncel Yaklaşımlar, 4(4), 520-546.

Bacanli, H., Illhan, T., \& Aslan, S. (2009). Beş faktör kuramına dayalı bir kişilik ölçeğinin geliştirilmesi: sıfatlara dayalı kişilik testi (SDKT). Journal of Turkish Educational Sciences, 7(2), 261-279.

Balkaya, F. (2006). Üniversite öğrencilerinde temas biçimlerinin öfke ve anksiyete ile ilişkisi. Yayımlanmamış Doktora Tezi, Ankara Üniversitesi, Ankara.

Baumrind, D. (1966). Effects of authoritative parental control on child behavior. Child development, 37 (4), $887-907$.

Bozkurt, S. (2006). Temas biçimleriyle bağlanma stilleri ve kişilerarası şemalar arasındaki ilişkinin incelenmesi. Gestalt Terapi Dergisi, 4(2).

Burley, T., \& Freier, M. C. K. (2004). Character structure: a gestalt-cognitive theory. Psychotherapy: Theory, Research, Practice, Training, 41(3), 321-331.

Büyükşahin, A. (2001). Yakın ilişki kuran ve kuramayan üniversite öğrencilerinin çeşitli sosyal psikolojik etkenler yönünden karşılaştrılması. Yayımlanmamış yüksek lisans tezi, Ankara Üniversitesi, Ankara.

Daş, C. (2015). Geştalt Terapi (6. Basım). Ankara: HYB Yayıncılık.

Evans, K. (2007). Living in the 21st Century: A Gestalt therapist's search for a new paradigm (Abstract). Gestalt Review, 11(3), $190-203$.

Gökdemir-Aktaş, C. (2002). Gestalt temas biçimleri ölçeği yeniden düzenlenmiş formun Türk örnekleminde faktör yapısı, geçerliği ve güvenirliği. Yayınlanmamış Yüksek Lisans Tezi, Ankara Üniversitesi, Ankara.

Gökdemir-Aktaş, C., \& Daş, C. (2002). Gestalt Temas Biçimleri Yeniden Düzenlenmiş Form'un Türk örnekleminde Faktör yapısı geçerliği ve güvenirliği. Temas: Gestalt Terapi Dergisi, 1(1), 81-108.

Gürdil, G. (2014). Üstlenilmiş travma ve ikincil travmatik stresin travmatik yaşantılara müdahale eden bir grup üzerinde Geştalt temas biçimleri çerçevesinde değerlendirilmesi. Yayımlanmamış doktora tezi, Ankara Üniversitesi, Ankara.

Gürsoy, Ü. (2009). Üniversite öğrencilerinin Gestalt temas biçimleri ile yaşam doyumları arasındaki ilişkinin Incelenmesi. Yayınlanmamış Yüksek Lisans Tezi, Marmara Üniversitesi, İstanbul.

Heiden, M. E. F. (2006). Gestalt Contact Styles/Resistances and the Masculine Experience of Intimacy. Disseration Abstracts International. (UMI Number: 3230489).

Karasar, N. (2009). Bilimsel araştırma yöntemi; kavramlar, ilkeler, teknikler. Ankara: Nobel Yayıncılık.

Kaya, M . (1997). Ailede anne-baba tutumlarının çocuğun kişilik ve benlik gelişimindeki rolü. Ondokuz Mayıs Üniversitesi Ilahiyat Fakültesi Dergisi, 9 (9), 193-204.

Kuyumcu, B. (2011). Evli Kişilerde Gestalt temas biçimleri ve bağlanma stilleri arasındaki ilişkinin incelenmesi. Mehmet Akif Ersoy Üniversitesi Sosyal Bilimler Enstitüsü Dergisi, 3(5), 57-70.

Levine, T. B. Y. (Ed.). (2012). Gestalt therapy: advances in dheory and practice. New York: Routledge.

Leong, F. T. (Ed.). (2008). Encyclopedia of counseling. Chicago: SAGE Publications.

Maccoby, E.E. \& Martin, J. A. (1983). Socialization in the Context of Family: Parent Child Interaction. In Mussen, P.H. and Hetherington, E.M. (Ed.) (pp. 1-101), Handbook of Child Psyhology: Socialition, Personality and Social Development. New York: Willey.

Mann, D. (2010). Gestalt therapy: 100 key points and techniques. New York: Routledge.

Murdock, N. L. (2012). Psikolojik danışma ve psikoterapi kuramları olgu sunumu yaklaşımıyla (F. Akkoyun, Çeviri Editörü). Ankara: Nobel Akademik Yayıncılık.

Myers, M. E. (1996). Police stress and Gestalt contact style. Unpublished Doctoral Dissertation, Kent State University, Ohio.

Özkara, P. (2015). Ufuk üniversitesi lisans öğrencilerinin temas engellerinin bazı değişkenler açısından incelenmesi. Yayımlanmamış Yüksek Lisans Tezi, Ufuk Üniversitesi, Ankara.

Perls, F., Hefferline, R. F., \& Goodman, P. (1951/1996). Gestalt therapy: excitement and growth in the human personality. Great Britain: The Guernsey Press Co.

Sakarya, S. (2008). Alkolik babaların yetişkin çocukları: psikolojik sağlıkları, kendi ve annelerinin stresle başa çıkma ve yakın ilişki kurma tarzları. Yayımlanmamış Doktora Tezi, Ankara Üniversitesi, Ankara.

Tagay, Ö., \& Acar, N. V. (2012). Gestalt temas engelleri ölçeğinin geliştirilmesi. Türk Psikolojik Danışma ve Rehberlik Dergisi, 4(37), 61-72. Wheeler, G., \& Axelsson, L. (2015). Gestalt therapy. Washington: American Psychological Association.

Vardal, E. (2015). Yeme tutumu: bağlanma stilleri ve Geştalt temas biçimleri açısından bir değerlendirme. Yayımlanmamış Yüksek Lisans Tezi, Ankara Üniversitesi, Ankara.

Yavuzer, H. (1990). Yaygın anne-baba tutumları. Ana baba okulu. İstanbul: Remzi Kitabevi. 